\title{
Salt Effects of Potassium Nitrate, Sodium Sulfate, and Trisodium Citrate on the Activity Coefficients of $p$-Phenolsulfonate Buffers
}

\author{
By Roger G. Bates, Pauline T. Diamond, Murray Eden, and S. F. Acree
}

\begin{abstract}
Electromotive-force measurements of cells without liquid junction that contained hydrogen and silver-silver-chloride electrodes and alkaline $p$-phenolsulfonate buffers with added salts of different valence types were made from $0^{\circ}$ to $60^{\circ} \mathrm{C}$. The 63 buffer solutions studied were prepared by the partial neutralization of potassium $p$-phenolsulfonate with sodium hydroxide, and each contained approximately equal molal amounts of potassium $p$-phenolsulfonate and of potassium sodium $p$-phenolate sulfonate. These solutions were classified into five series on the basis of the kind of added salt and the ratio, $R$, of its molality to the molality of each buffer salt, as follows: Potassium nitrate, $R=1$; sodium sulfate, $R=1$; sodium sulfate, $R=0.5$; barium chloride, $R=0.5$; trisodium citrate, $R=0.33$. All the buffers, with the exception of the series to which barium chloride was added, likewise contained sodium chloride, $R=1$. The ionic strengths of the solutions varied from 0.05 to 0.8 .

The values of the second dissociation constant of $p$-phenolsulfonic acid given in an earlier paper were confirmed. The influence of potassium nitrate, sodium sulfate, and trisodium citrate on the activity coefficient term, $f_{\mathrm{Cl}} f_{\mathrm{HPs}} / f_{\mathrm{Ps}}$, in which $f$ represents an activity coefficient on the molal scale and the subscripts represent respectively chloride ion and the primary and secondary anions of the buffer, was determined for solutions containing no sodium chloride at $0^{\circ}$ to $35^{\circ} \mathrm{C}$. No pronounced differences in character were observed among the effects of the salts of the three valence types in concentrations sufficient to make up one-fifth of the ionic strength of the mixture.
\end{abstract}

\section{Salt Effect on the $\mathrm{pH}$ of Buffered Solutions}

Addition of a neutral salt to a buffer solution composed of the primary and secondary salts of a weak dibasic or polybasic acid normally results in an increase in the acidity of the solution. Inadequate knowledge of the activity coefficients in mixtures of electrolytes and of their role in the behavior of a system in homogeneous equilibrium however, often makes it impossible to predict quantitatively the effect of salt on the $\mathrm{pH}$.

The $\mathrm{pH}$ of a buffer composed of potassium $p$-phenolsulfonate (KHPs) and of potassium sodium $p$-phenolate sulfonate $(\mathrm{KNaPs})$ can be expressed by the mass-law equation in loga-

\section{Contents}

I. Salt effect on the $\mathrm{pH}$ of buffered solutions_._._. 251

II. Method of evaluating the effect of salts on the

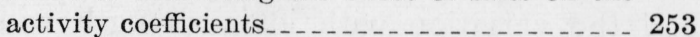

III. Experimental procedures and results _ _ _._. _. 254

1. Buffers with added potassium nitrate _._- 254

2. Buffers with added sodium sulfate _._. 255

3. Buffers with added barium chloride _._. 255

4. Buffers with added trisodium citrate____ 256

IV. Second dissociation constant of $p$-phenolsulfonic acid _.......... 257

V. Effect of neutral salts on the activity coefficients 258

1. Buffer solutions without added salt_. _. 258

2. Buffer solutions with added salt _ . . . . . 259

VI. References _...... 261 
rithmic form, with the appropriate activity coefficients, as follows:

$$
\mathrm{pH}=\mathrm{p} K-\log \left(m_{\mathrm{HPs}} / m_{\mathrm{Ps}}\right)-\log \left(f_{\mathrm{HPs}} / f_{\mathrm{Ps}}\right),
$$

where $\mathrm{p} K$ is the negative of the common logarithm of the dissociation constant of the phenol group of $p$-phenolsulfonic acid on the molal scale, $m$ represents molality (moles/1,000 g of water), and $f$ is the activity coefficient on the corresponding scale. It is evident that the change of $\mathrm{pH}$ with addition of neutral salt to a phenolsulfonate buffer must result largely from changes in the activity coefficients of the two anions of the buffer.

The change in $\mathrm{pH}$ when salt is added to the buffer solution is called the total salt effect. If provision is made for the effect of hydrolysis upon the molal ratio (second term on the right of eq 1 ), and the molalities of the components of the buffer remain unaltered, the change of the last term of eq 1 upon addition of salt measures the total salt effect.

It may reasonably be supposed that the change of the activity-coefficient term when the ionic strength of the solution changes at constant buffer ratio as a result of a variation in buffer concentration alone can be expressed by an equation such as the following:

$$
\log \frac{f_{\mathrm{HPs}}}{f_{\mathrm{Ps}}}=\frac{3 A \sqrt{\mu}}{1+B a \sqrt{\mu}}+\beta \mu,
$$

where $A$ and $B$ are constants of the Debye-Hückel equation, $\mu$ is the ionic strength, and $a$ and $\beta$ are parameters characteristic of the mixture of ions. The values of $a$ and $\beta$ evidently control the rate of change of $\log \left(f_{\mathrm{HPs}} / f_{\mathrm{Pg}}\right)$ with ionic strength and, hence, the total salt effect. When neutral salt is added to a buffer solution, the character of the variation of the activity-coefficient term with ionic strength may be unaffected. On the other hand, $a$ and $\beta$ may change as a result of interactions of the buffer ions with those of the salt, and the variation with ionic strength will then be different.

The total salt effect, therefore, can be of two types. The effect of salt addition is of the first type when the change of $\mathrm{pH}$ produced is the same as would normally result from an increase in ionic strength of the buffer alone, without the introduction of foreign ions or molecules. Thus, the $\mathrm{pH}$ of the mixture of buffer and salt will be the same as that of a more concentrated buffer of the same ionic strength and buffer ratio, without added salt. In other words, the rate of change of the activitycoefficient term with ionic strength remains unaltered when a neutral salt is substituted for an amount of buffer mixture which contributes the same increment to the ionic strength.

The second type of salt effect is the result of specific or abnormal interactions among the ions of the mixture. In the extreme case, these interactions may alter not only the activity coefficients of the buffer ions but their concentrations as well. Polar compounds, polymers, or complex ions may even be formed. These effects cause the activitycoefficient term to change in an abnormal manner with changing ionic strength. As a result, the $\mathrm{pH}$ of the bufier with salt differs from that of a pure buffer solution of the same ionic strength and buffer ratio.

In most cases, the effect of salt is probably of the more general second type. Furthermore, the term log $\left(f_{\mathrm{HPs}} / f_{\mathrm{Ps}}\right)$ at constant ionic strength may reasonably be expected to vary linearly with composition of the solution. When the kinds of ions added are similar to those of the buffer, however, it is possible that they will alter the activity-coefficient term by the same amount as would the buffer ions, added in like quantity. A salt effect of the second type may, of course, appear to be of the first type when the amount of salt added is small compared with the ionic strength of the buffer itself.

The problem of determining salt effects on the phenolsulfonate buffer is resolved into a determination of the changes in the activity coefficients on addition of salt. Unfortunately, the ratio of the activity coefficients of the primary and secondary anions, $f_{\mathrm{HP}_{\mathrm{s}}} / f_{\mathrm{Ps}}$, cannot readily be measured. In this investigation, the character of the salt effect of potassium nitrate, sodium sulfate, and trisodium citrate on the activity coefficients of these ions was studied by evaluating the activitycoefficient term, $f_{\mathrm{HPs}} / \mathrm{Cl} / f_{\mathrm{Ps}}$, in buffered solutions of sodium chloride with and without one of the three neutral salts. In order that the observed effect might represent as closely as possible the influence of the salt on the buffer ions alone, the activity-coefficient term was evaluated in the limit of zero sodium chloride from $0^{\circ}$ to $35^{\circ} \mathrm{C}$.

Electromotive-force measurements at $0^{\circ}$ to $60^{\circ}$ C were made with buffer mixtures composed of sodium chloride and approximately equal molal amounts of potassium $p$-phenolsulfonate and 
potassium sodium $p$-phenolate sulfonate without added salt, and for similar buffers which contained potassium nitrate, sodium sulfate, or trisodium citrate. One series contained barium chloride instead of sodium chloride. The effects of the three alkali salts of different valence types on the activity coefficients were found to be approximately the same when the added salt made up one-fifth of the total ionic strength. The emf data for these buffer solutions with added salt, together with those for the series of buffers that contained chloride, confirm the values for the second dissociation constant of $p$-phenolsulfonic acid found in an earlier study [1]. ${ }^{1}$

1 Figures in brackets indicate the literature references at the end of this paper.

\section{Method of Evaluating the Effect of Salts on the Activity Coefficients}

Electromotive-force measurements of cells of the type

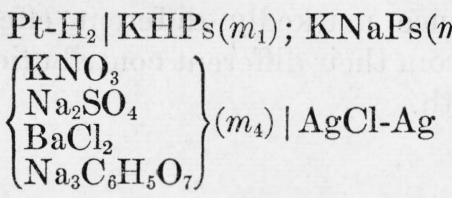

were made at intervals of 5 degrees from $0^{\circ}$ to $60^{\circ} \mathrm{C}$. The chemical changes that result from drawing a finite current from this cell are given by the complete cell reaction,

$$
1 / 2 \mathrm{H}_{2}+\mathrm{AgCl}+\mathrm{Ps}^{=}=\mathrm{Ag}+\mathrm{Cl}^{-}+\mathrm{HPs}^{-},
$$

for which the standard free energy change, $-\Delta F^{\circ *}$, is

$$
-\Delta F^{\circ *}=E^{\circ *} \boldsymbol{F}=R T \ln K^{*},
$$

where $E^{\circ *}$ is the potential of the hypothetical cell of type I, in which each of the components has an activity of unity; $K^{*}$ is the thermodynamic equilibrium constant for eq 3 ; and $R, T$, and $\boldsymbol{F}$ are the gas constant, the absolute temperature, and the faraday.

The total reaction in the cell may be written in two parts. The first of these is the electrode reaction,

$$
1 / 2 \mathrm{H}_{2}+\mathrm{AgCl}=\mathrm{Ag}+\mathrm{H}^{+}+\mathrm{Cl}^{-} ;-\Delta F_{1}^{\circ}=E^{\circ} F,
$$

where $E^{\circ}$ is the standard potential of the cell, $\mathrm{H}_{2}|\mathrm{HCl}| \mathrm{AgCl}-\mathrm{Ag}$, and the other is a homogeneous equilibrium that involves the hydrogen ion formed by the electrode reaction, namely, the equilibrium between the primary and secondary anions of phenolsulfonic acid,

$$
H \mathrm{Ps}^{-}=\mathrm{H}^{+}+\mathrm{Ps}^{=} ;-\Delta F_{2}^{\circ}=R T \ln K .
$$

The constant $K$ in eq 6 is the thermodynamic second dissociation constant for the acid. It has been determined by Bates, Siegel, and Acree [1] over the range of temperatures from $0^{\circ}$ to $60^{\circ} \mathrm{C}$. From eq 4, 5, and 6 it is evident that

$$
\begin{aligned}
E^{\circ *} & =E^{\circ}-(R T / \boldsymbol{F}) \ln K \\
& =E^{\circ}+(2.3026 R T / F) \mathrm{p} K,
\end{aligned}
$$

where $\mathrm{p} K$ is the negative of the common logarithm of $K$. Values of $E^{\circ}$ at $0^{\circ}$ to $60^{\circ} \mathrm{C}$ have been recalculated by Hamer, Burton, and Acree [2] from the emf data of Harned and Ehlers [3].

The relation between emf, $E$, and the molalities and activity coefficients of the reactants and products of the cell reaction is

$$
\frac{E-E^{\circ *}}{k}+\log \frac{m_{\mathrm{HPs}} m_{\mathrm{C} 1}}{m_{\mathrm{Ps}}}=-\log \frac{f_{\mathrm{HPs}} f_{\mathrm{C} 1}}{f_{\mathrm{Ps}}},
$$

where $k$ is written for $2.3026 R T / F$. The activitycoefficient term in the equilibrium constant for reaction 3 can be computed from the emf by eq 8 . By observing the behavior of the emf and, through it, the activity-coefficient term when neutral salts of different valence types are added to the buffered chloride solutions, information can be gained regarding the nature of the effect of added salt on the three ions involved in the cell reaction.

In solutions that contained neutral salts, as in buffered chloride solutions without added salts [4], the experimental values of the last term of eq 8 could be represented satisfactorily by an equation of the type

$$
\log \frac{f_{\mathrm{HP}} f_{\mathrm{C} 1}}{f_{\mathrm{Ps}}}=\frac{2 A \sqrt{\mu}}{1+B a * \sqrt{\mu}}+\beta^{*} \mu,
$$

derived from the Debye-Hückel theory. Inasmuch as a confirmation of the value of $\mathrm{p} K$ was desired, $a^{*}$ and $\beta^{*}$ were evaluated as before [1] from the graphs used to derive this constant by extrapolation of the values of $\mathrm{p} K^{\prime}$, the negative logarithm of the "apparent" dissociation constant, to an ionic strength of zero. 
$\mathrm{p} K^{\prime}$ is defined through a combination of eq 7 , 8, and 9:

$$
\begin{aligned}
& \mathrm{p} K^{\prime}=\mathrm{p} K-\beta^{*} \mu=\frac{E-E^{\circ}}{k}+\log \frac{m_{\mathrm{HPs}} m_{\mathrm{Cl}}}{m_{\mathrm{Ps}}}+ \\
& \frac{2 A \sqrt{\mu}}{1+B a^{*} \sqrt{\mu}} .
\end{aligned}
$$

In the range of temperatures from $0^{\circ}$ to $35^{\circ} \mathrm{C}$, $a^{*}$ and $\beta^{*}$ were also determined for phenolsulfonate buffers with and without neutral salt at several different concentrations of sodium chloride. The values of these parameters were plotted as a function of $m_{\mathrm{NaCl}} / \mu$, the fractional contribution of sodium chloride to the ionic strength, and the corresponding values, $a^{\circ}$ and $\beta^{\circ}$, in the absence of sodium chloride were obtained by extrapolation. The value of the activity-coefficient term in the limit of zero sodium chloride, $f_{R}^{\circ}$, is defined by

$$
\log f_{R}^{\circ} \equiv \log \left[\frac{f_{\mathrm{HPs}} f_{\mathrm{C} 1}}{f_{\mathrm{Ps}}}\right]_{m_{\mathrm{Cl}}=0}=\frac{2 A \sqrt{\mu}}{1+B a^{\circ} \sqrt{\mu}}+\beta^{\circ} \mu .
$$

It is impossible to compute the change of $\mathrm{pH}$ upon addition of salt to the buffer solution from the measured change in $f_{B}^{\circ}$ without recourse to an arbitrary assumption regarding the relative magnitudes of the individual activity coefficients. The parameters $a^{\circ}$ and $\beta^{\circ}$ might, for example, be identified with $a$ and $\beta$ of eq 2 , or a relation such as $\log f_{\mathrm{Cl}}=-(1 / 3) \log \left(f_{\mathrm{HP}} / f_{\mathrm{Ps}_{\mathrm{s}}}\right)$, based upon valence effects in very dilute solutions, be introduced. The influence of neutral salt on $\log f_{R}^{\circ}$ should, however, approximate in character the salt effect on the buffer anions alone. From these results, therefore, an estimate could be made of (a) the magnitude of the change in the activity-coefficient term of eq 1 when small concentrations of salt are added to the buffer and (b) whether salts of different types produce markedly different effects on the $\mathrm{pH}$, apart from their different contributions to the ionic strength.

\section{Experimental Procedures and Results}

The buffer solutions were made by the weight dilution of stock solutions that were prepared in quantities of two liters each from weighed amounts of potassium $p$-phenolsulfonate and a standard solution of carbonate-free sodium hydroxide. Each stock solution, with the exception of the one to which barium chloride was added, also contained both sodium chloride and one of the three neutral salts ${ }^{2}$ chosen for study. The specific conductance of the water was in most cases about $0.5 \times 10^{-6}$ mho.

The potassium phenolsulfonate analyzed 100.10 percent by titration with alkali. The sodium chloride was part of the same fused sample used in earlier work on phenolsulfonate buffers $[1,4]$. It was found by titration with acid to contain 0.007 percent by weight of free alkali. This amount of impurity changes the emf of the cell by less than $0.01 \mathrm{mv}$ and can safely be ignored. Description of the equipment, methods of preparing the electrodes, and other experimental details have been given elsewhere $[1,5]$.

The emf data for cell I are given in the sections to follow. In each of the 63 buffers, $m_{1}$ and $m_{2}$ were approximately equal. When sodium chloride

\footnotetext{
2 A neutral salt is considered here to be one that has no appreciable buffer capacity at $\mathrm{pH} 8.4$ to 9.2. Inasmuch as hydrogen and silver-silver-chloride electrodes were used, chlorides, bromides, iodides, sulfides, and substances readily reduced by hydrogen in alkaline solution were excluded.
}

was present, its molality was usually nearly the same as that of each buffer salt, except in series F, where the ratio of chloride to buffer was varied. The ratio, $R$, of $m_{4}$ to $m_{1}$ was approximately unity for solutions that contained potassium nitrate, 1 and 0.5 for sodium sulfate, and 0.33 for trisodium citrate. Sodium chloride was absent from series $\mathrm{D}$, and barium chloride $(R=0.5)$ was present.

The combined experimental errors in the compositions of the solutions and in the emf measurements, together with the errors in the values of the natural constants and the standard potential, are thought not to exceed $0.18 \mathrm{mv}$ at any temperature. The uncertainty from these sources amounts to 0.003 in the activity-coefficient term of eq 9 or eq 11.

\section{Buffers With Added Potassium Nitrate}

Potassium nitrate of reagent quality was recrystallized once from water and dried to constant weight at $110^{\circ} \mathrm{C}$. Preliminary experiments showed that satisfactory results could be obtained with the hydrogen electrode in solutions that contained nitrate ion in moderate concentration in a phenolsulfonate buffer at a $\mathrm{pH}$ of 8.8. The hydrogen electrodes in solutions containing 0.06 - to $0.1-m$ potassium nitrate, however, oc- 
casionally gave erratic potentials and had to be replaced. No larger differences between the initial and final emf at $25^{\circ} \mathrm{C}$ were found, however, with nitrates than with other salts, and the dilute solutions were satisfactory in every respect. The emf results for 1:1 buffers with added potassium nitrate are given in table 1 .

TABLE 1.-Electromotive forces of hydrogen-silver-chloride cells containing mixtures of potassium p-phenolsulfonate $\left(m_{1}\right)$, poiassium sodium $p$-phenolate sulfonate $\left(m_{2}\right)$, sodium chloride $\left(m_{3}\right)$, and potassium nitrate $\left(m_{4}\right)$

$\left[m_{2}=0.9785 m_{1} ; m_{3}=0.9349 m_{1} ; m_{4}=0.9332 m_{1}\right]$

\begin{tabular}{|c|c|c|c|c|c|c|c|}
\hline $\begin{array}{l}\text { Solution num- } \\
\text { ber }\end{array}$ & $m_{1}$ & $E_{0}^{\circ}$ & $E_{5}{ }^{\circ}$ & $E_{10^{\circ}}$ & $E_{15^{\circ}}$ & $E_{20^{\circ}}$ & $E_{25^{\circ}}$ \\
\hline $\mathrm{A} 1 .$. & 0.10830 & 0.78654 & 0.78003 & 0. 79339 & 0.79676 & 0. 79998 & 0.80319 \\
\hline A2 & .08572 & .79168 & .79534 & .79874 & .80232 & .80571 & .80910 \\
\hline A3... & .04450 & .80721 & .81123 & .81510 & .81896 & .82238 & .82675 \\
\hline A4 & .03591 & .81270 & .81690 & - . & .82457 & .82856 & .83269 \\
\hline A5 & .02520 & .82172 & .82609 & .83027 & .83450 & .83856 & .84263 \\
\hline A6. & .013753 & .83706 & .84176 & .84626 & .85079 & .85511 & .85958 \\
\hline A7 & .011864 & .84087 & .84559 & .85019 & .85476 & .85927 & .86374 \\
\hline \multirow[t]{2}{*}{ A8 } & .008651 & .84873 & .85352 & .85844 & .86319 & .86785 & .87258 \\
\hline & $E_{30}{ }^{\circ}$ & $E_{35^{\circ}}{ }^{\circ}$ & $E_{40}{ }^{\circ}$ & $E_{45^{\circ}}^{\circ}$ & $E_{50}{ }^{\circ}$ & $E_{55^{\circ}}$ & $E_{00^{\circ}}$ \\
\hline A1. & & 0.80932 & 0.81264 & 0.81570 & 0.81901 & c. 82204 & 0.82503 \\
\hline A2.. & - & .81558 & .81904 & .82217 & .82555 & .82879 & .83211 \\
\hline A3.. & 0.83042 & & .83732 & .84114 & .84516 & .84885 & .85248 \\
\hline A4. & .83659 & & .84407 & .84785 & .85188 & .85562 & .85930 \\
\hline A5 $\ldots$ & .84670 & .85055 & .85454 & .85859 & .86261 & .86654 & .87046 \\
\hline A6. & .86392 & .86801 & .87253 & .87670 & .88096 & .88512 & .88930 \\
\hline A7 & .86821 & .87239 & .87697 & .88121 & .88510 & .88982 & .89409 \\
\hline A8 $\ldots$ & .87725 & .88157 & .88635 & .89177 & .89534 & .89977 & .90423 \\
\hline
\end{tabular}

\section{Buffers with added sodium sulfate}

Sodium sulfate, of the grade designated "for nitrogen determination", was recrystallized twice from water. The water of hydration was removed by drying the salt in a vacuum oven at temperature up to $100^{\circ} \mathrm{C}$ and at $130^{\circ} \mathrm{C}$ under atmospheric pressure. Two ratios of anhydrous sodium sulfate to buffer were studied. The buffers of series B contained approximately equal molal amounts of sodium sulfate and of each buffer salt, whereas the five solutions in series $\mathrm{C}$ contained one-half as much added salt as buffer. The emf values at $0^{\circ}$ to $60^{\circ} \mathrm{C}$ are given in table 2 .

\section{Buffers with Added Barium Chloride}

Measurements were made of one series of phenolsulfonate buffers in which barium chloride was substituted for sodium chloride. The method outlined earlier in this paper obviously cannot serve to determine the salt effect of barium chloride on
TABLE 2.-Electromotive forces of hydrogen-silver-chloride cells containing mixtures of potassium p-phenolsulfonate $\left(m_{1}\right)$, potassium sodium p-phenolate sulfonate $\left(m_{2}\right)$, sodium chloride $\left(m_{3}\right)$, and sodium sulfate $\left(m_{4}\right)$.

[Solutions B1 to B5: $m_{2}=0.9916 m_{1} ; m_{3}=0.9425 m_{1} ; m_{4}=0.9727 m_{1}$. Solutions B6 to B11: $m_{2}=1.0150 m_{1} ; m_{3}=0.9512 m_{1} ; m_{4}=0.9554 m_{1}$. Solutions B12 to B20: $m_{2}=0.9803 m_{1} ; m_{3}=0.9455 m_{1} ; m_{4}=0.9444 m_{1}$. Series C: $m_{2}=0.9743 m_{1}$ $\left.m_{3}=0.9413 m_{1} ; m_{4}=0.4732 m_{1}\right]$

\begin{tabular}{|c|c|c|c|c|c|c|c|}
\hline $\begin{array}{l}\text { Solution } \\
\text { number }\end{array}$ & $m_{1}$ & $E_{0}^{\circ}$ & $E_{5}^{\circ}{ }^{\circ}$ & $E_{10^{\circ}}$ & $E_{15}^{\circ}$ & $E_{20}^{\circ}$ & $E_{25}^{\circ}$ \\
\hline B1. & 0. 10686 & & & & & & 0.80234 \\
\hline B2. & .06602 & & & & & 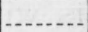 & .81520 \\
\hline B3. & .05438 & & & & & & .82054 \\
\hline B4. & .02030 & & & & & & .84785 \\
\hline B5. & .010524 & & & & & & .86636 \\
\hline B6. & .10443 & 0.78644 & 0.78993 & c. 79333 & 0. 79672 & 0.80007 & .80339 \\
\hline B7. & .06808 & .79660 & .80032 & .80407 & .80772 & .81130 & .81490 \\
\hline B8. & .04623 & .80607 & .81007 & .81393 & .81776 & .82154 & .82535 \\
\hline B9. & .02709 & .81939 & .82377 & .82793 & .83205 & .83619 & .84030 \\
\hline B10 . & .013336 & .83763 & .84232 & .84684 & .85134 & .85580 & .86027 \\
\hline B11. & .013036 & .83798 & .84271 & .84725 & .85172 & .85620 & .86073 \\
\hline B12. & .10722 & .78516 & .78866 & .79216 & .79557 & .79872 & .80207 \\
\hline B13. & .08036 & .79189 & .79553 & .79918 & .80281 & .80618 & .80965 \\
\hline B14. & .06067 & .79879 & .80261 & .80641 & .81012 & .81365 & .81731 \\
\hline B15 . & .04181 & .80796 & .81197 & .81598 & .81993 & .82366 & .82749 \\
\hline B16. & .02823 & .81766 & .82190 & .82612 & .83029 & .83430 & .83832 \\
\hline B17. & .015906 & .83247 & .83701 & .84148 & .84597 & .85028 & .85462 \\
\hline B18. & 014489 & .83486 & .83941 & .84393 & .84844 & .85280 & .85719 \\
\hline B19. & .009284 & .84621 & .85099 & .85579 & .86055 & .86506 & .86970 \\
\hline B20. & .006629 & .85475 & .85963 & .86459 & .86953 & .87434 & .87927 \\
\hline C1. & .08524 & .79022 & .79431 & .79789 & .80125 & .80490 & .80833 \\
\hline $\mathrm{C} 2$ & .05903 & .79965 & .80367 & .80743 & .81098 & .81469 & .81842 \\
\hline C3. & .03767 & .81078 & .81504 & .81908 & .82277 & .82677 & .83072 \\
\hline $\mathrm{C} 4$ & .018541 & .82872 & .83313 & .83766 & .84195 & .84629 & .85057 \\
\hline C5. & 010837 & .84253 & .84733 & .85199 & .85666 & .86122 & .86582 \\
\hline & $E_{30^{\circ}}$ & $E_{35^{\circ}}^{\circ}$ & $E_{40^{\circ}}$ & $E_{45^{\circ}}^{\circ}$ & $E_{50^{\circ}}^{\circ}$ & $E_{55^{\circ}}^{\circ}$ & $E_{60}^{\circ}$ \\
\hline B1. & 0.80569 & 0.80883 & & & & & \\
\hline B2. & .81876 & .82234 & & & & & - \\
\hline B3. & .82420 & .82782 & & & & & \\
\hline B4. & .85207 & .85634 & & & & & \\
\hline B5 & .87092 & .87542 & & & & & - \\
\hline B6. & .80676 & .81002 & 0.81330 & 0.81652 & 0.81973 & 0.82287 & 0.82609 \\
\hline B7. & .81852 & .82201 & .82551 & .82895 & .83235 & .83576 & .83914 \\
\hline B8. & .82912 & .83284 & .83655 & .84016 & .84375 & .84741 & .85097 \\
\hline B9. & .84440 & .84838 & .85237 & .85631 & .86020 & .86407 & .86792 \\
\hline B10 & .86467 & .86903 & .87336 & .87768 & .88196 & .88616 & .89038 \\
\hline B11. & .86508 & .86948 & .87389 & .87802 & .88213 & .88634 & .89016 \\
\hline B12_ & .80535 & .80861 & .81193 & .81508 & .81827 & .82140 & .82450 \\
\hline B13. & .81308 & .81656 & .82000 & .82330 & .82669 & $.83 \mathrm{C} 01$ & .83332 \\
\hline B14. & .82087 & .82444 & .82805 & .83155 & .83501 & .83844 & .84189 \\
\hline B15 . & .83128 & .83506 & .83885 & .84252 & .84621 & .84986 & .85351 \\
\hline B16. & .84238 & .84637 & .85036 & .85424 & .85814 & .86200 & .86583 \\
\hline B17. & .85894 & .86321 & .86756 & .87177 & .87597 & .88012 & .88425 \\
\hline $\mathrm{B} 18$ & .86157 & .86589 & .87025 & .87449 & .87872 & .88290 & .88704 \\
\hline B19. & .87430 & .87886 & .88344 & .88788 & .89232 & .89672 & .90098 \\
\hline B20_ & .88391 & .88862 & .89313 & .89774 & .90238 & .90703 & .91143 \\
\hline $\mathrm{C} 1$. & .81175 & .81512 & .81854 & .82192 & .82524 & .82855 & .83184 \\
\hline C2. & .82199 & .82561 & .82923 & .83275 & .83628 & .83975 & .84325 \\
\hline C3.- & .83450 & .83841 & .84224 & .84601 & .84971 & .85346 & .85710 \\
\hline C4. & .85480 & .85892 & .86311 & .86726 & .87139 & .87551 & .87956 \\
\hline C5.- & .87031 & .87485 & .87931 & .88373 & .88814 & .89248 & .89679 \\
\hline
\end{tabular}


the properties of the buffer anions alone, for it is impossible to obtain the activity-coefficient term at zero ratio of chloride to buffer and maintain, at the same time, a constant ratio of buffer to added salt. A series of measurements of solutions containing barium chloride was considered desirable, however, to aid in determining $\mathrm{p} K$ as accurately as possible.

Barium chloride, of reagent grade, was purified by recrystallization from water, powdered, and dried at $125^{\circ} \mathrm{C}$. The emf data for phenolsulfonate buffers with added barium chloride are given in table 3.

TABLE 3.-Electromotive forces of hydrogen-silver-chloride ceils containing mixtures of potassium p-phenosulfonate $\left(m_{1}\right)$, potassium sodium $p$-phenolate sulfonate $\left(m_{2}\right)$, and barium chloride $\left(m_{4}\right)$

$\left[m_{2}=0.9854 m_{1} ; m_{4}=0.5092 m_{1}\right]$

\begin{tabular}{|c|c|c|c|c|c|c|c|}
\hline $\begin{array}{l}\text { Solution } \\
\text { number }\end{array}$ & $m_{1}$ & $E_{0}^{\circ}$ & $E_{5}^{\circ}$ & $E_{10}{ }^{\circ}$ & $E_{15}^{\circ}$ & $E_{20}^{\circ}$ & $E_{25}^{\circ}$ \\
\hline D1. & 0.07950 & 0. 79066 & 0. 79435 & 0. 79801 & 0.80128 & 0.80489 & 0.80844 \\
\hline D2. & .07455 & .79223 & .79596 & .79964 & .80303 & .80665 & .81018 \\
\hline D3... & .05521 & .79959 & .80349 & .80733 & .81096 & .81470 & .81838 \\
\hline D4 & .03890 & .80821 & .81229 & .81632 & .82022 & .82412 & .82801 \\
\hline D5 & .03033 & .81468 & .81885 & .82295 & .82702 & .83104 & .83513 \\
\hline D6... & .02901 & .81556 & .81979 & .82394 & .82802 & .83203 & .83606 \\
\hline D7 & .018064 & .82779 & .83226 & .83666 & .84092 & .84527 & .84958 \\
\hline D8 & .015583 & .83163 & .83621 & .84073 & .84509 & .84948 & .85381 \\
\hline D9 & .012138 & .83800 & .84263 & .84722 & .85171 & .85622 & .86070 \\
\hline \multirow[t]{2}{*}{ D10 } & .008828 & .84626 & .85110 & .85590 & .86054 & .86523 & .86983 \\
\hline & $E_{30^{\circ}}$ & $E_{35^{\circ}}$ & $E_{40^{\circ}}$ & $E_{45^{\circ}}^{\circ}$ & $E_{50}^{\circ}$ & $E_{55}^{\circ}$ & $E_{60}^{\circ}$ \\
\hline D1. & 0.81183 & 0.81518 & 0.81868 & 0.82198 & 0.82528 & 0.82864 & 0.83188 \\
\hline D2 & .81366 & .81702 & .82053 & .82390 & .82724 & .83059 & .83390 \\
\hline D3. & .82205 & .82564 & .82925 & .83280 & .83632 & .83979 & .84324 \\
\hline D4 & .83188 & .83566 & .83951 & .84325 & .84696 & .85072 & .85428 \\
\hline D5 & - & $-\ldots$ & . & - & - & - & . \\
\hline D6 & .84008 & .84399 & .84793 & .85183 & .85569 & .85951 & .86326 \\
\hline D7 & .85380 & .85794 & .86215 & .86629 & .87039 & .87442 & .87848 \\
\hline D8 & .85816 & .86253 & .86659 & .87080 & .87495 & .87911 & .88319 \\
\hline D9 & .86516 & .86952 & .87394 & .87827 & .88256 & .88680 & .89102 \\
\hline D10 & .87449 & .87901 & .88350 & .88798 & .89242 & .89683 & .90104 \\
\hline
\end{tabular}

\section{Buffers with added trisodium citrate}

In the search for a neutral salt that would yield trivalent ions, trisodium citrate was chosen. A preparation of the salt, of reagent grade, was crystallized from water and dried to constant weight at $130^{\circ} \mathrm{C}$.

The $\mathrm{pH}$ change when small amounts of sodium hydroxide were added to a $0.05-m$ solution of trisodium citrate was determined with the use of thymol blue. The $\mathrm{pH}$ was found to increase from 8.4 to 9.0 upon the addition of $5 \times 10^{-5}$ mole of the alkali to a liter of the citrate solution. Thus, $m_{1} / m_{2}$ for a $0.1-m$ phenolsulfonate buffer initially
TABLE 4.-Electromotive forces of hydrogen-silver-chloride cells containing mixtures of potassium p-phenolsuifonate $\left(m_{1}\right)$, potassium sodium p-phenolate sulfonate $\left(m_{2}\right)$, sodium chloride $\left(m_{3}\right)$, and trisodium citrate $\left(m_{4}\right)$.

$\left[m_{2}=0.9388 m_{1} ; m_{3}=0.9521 m_{1} ; m_{4}=0.3334 m_{1}\right]$

\begin{tabular}{|c|c|c|c|c|c|c|c|}
\hline $\begin{array}{l}\text { Solution } \\
\text { number }\end{array}$ & $m_{1}$ & $E_{0}{ }^{\circ}$ & $E_{5}^{\circ}$ & $E_{10}{ }^{\circ}$ & $E_{15}^{\circ}{ }^{\circ}$ & $E_{20}{ }^{\circ}$ & $E_{25}^{\circ}$ \\
\hline E1. & 0.10611 & 0.78554 & 0.78897 & 0.79242 & 0.79582 & 0.79903 & 0.80267 \\
\hline E2 & .08339 & .79134 & .79498 & .79855 & .80209 & .80549 & .80904 \\
\hline E3. & .07267 & . & ......... & $\ldots$ & . n & .......... & .81271 \\
\hline E4.. & .05579 & .80101 & .80487 & .80867 & .81236 & .81598 & .81991 \\
\hline E5.- & .04833 & .80458 & .80864 & .81241 & .81626 & .81996 & .82376 \\
\hline E6... & .02841 & .81779 & .82208 & .82628 & .83042 & .83441 & .83856 \\
\hline E7. & .02052 & .82627 & .83072 & .83505 & .83934 & .84345 & .84789 \\
\hline E8 & .010988 & .84187 & .84670 & .85136 & .85608 & .86049 & .86526 \\
\hline E9. & .007951 & .85041 & .85529 & .86013 & .86488 & .86952 & .87451 \\
\hline \multirow[t]{2}{*}{$\mathrm{E} 10$} & .005326 & & & & & $\ldots$ & .88558 \\
\hline & $E_{30}{ }^{\circ}$ & $E_{35^{\circ}}{ }^{\circ}$ & $E_{40^{\circ}}$ & $E_{45^{\circ}}{ }^{\circ}$ & $E_{50^{\circ}}$ & $E_{55^{\circ}}{ }^{\circ}$ & $E_{60}^{\circ}$ \\
\hline E1.. & 0.80590 & 0.80855 & 0.81178 & 0.81523 & 0.81840 & 0.82145 & 0.82486 \\
\hline E2 & .81243 & .81591 & .81930 & .82263 & .82596 & .82927 & .83257 \\
\hline E3.. & . & 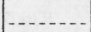 & - & .... & - n & - & . \\
\hline E4. & .82363 & .82726 & .83085 & .83441 & .83795 & .84147 & .84496 \\
\hline E5_.. & .82747 & .83111 & .83478 & .83858 & .84213 & .84557 & .84921 \\
\hline E6 - - & .84270 & .84666 & .85062 & .85460 & .85852 & .86239 & .86618 \\
\hline E7 & .85193 & .85607 & .86021 & .86431 & .86839 & .87233 & .87633 \\
\hline E8 & .86971 & .87421 & .87871 & .88317 & .88749 & .89175 & .89601 \\
\hline E9..... & .87910 & .88375 & .88833 & .89295 & .89742 & .90197 & .90643 \\
\hline E10. & $\ldots$ & - & - & $\ldots$ & ......... & - & - . \\
\hline
\end{tabular}

TABLE 5.-Electromotive forces of hydrogen-silver-chloride cells containing mixtures of potassium p-phenolsulfonate $\left(m_{1}\right)$, potassium sodium $p$-phenolate sulfonate $\left(m_{2}\right)$, with added neutral salt $\left(m_{4}\right)$, and varying molalities of sodium chloride $\left(m_{3}\right)$

\begin{tabular}{|c|c|c|c|c|c|c|}
\hline $\begin{array}{l}\text { Solution } \\
\text { number }\end{array}$ & $m_{1}$ & $m_{2}$ & $m_{3}$ & $\begin{array}{c}m_{4} \\
\left(\mathrm{KNO}_{3}\right)\end{array}$ & $E_{0}^{\circ}$ & $E_{5}^{\circ}$ \\
\hline F1... & 0.04300 & 0.04309 & 0.02589 & 0.04310 & 0.81898 & 0.82314 \\
\hline F2 & .04300 & .04309 & .016602 & .04310 & .82957 & .83395 \\
\hline \multirow{2}{*}{ F3 } & .04300 & .04309 & .008233 & .04310 & .84599 & .85071 \\
\hline & \multirow{6}{*}{$\begin{array}{l}.04300 \\
.04300 \\
.04300 \\
.04300\end{array}$} & \multirow{6}{*}{$\begin{array}{l}.04309 \\
.04309 \\
.04309 \\
.04309\end{array}$} & \multirow{6}{*}{$\begin{array}{l}.02557 \\
.015982 \\
.008634 \\
.008038\end{array}$} & $\begin{array}{c}m_{4} \\
\left(\mathrm{Na}_{2} \mathrm{SO}_{4}\right)\end{array}$ & & \\
\hline F4 & & & & .04310 & .81869 & .82280 \\
\hline F5 & & & & .04310 & .82770 & .83400 \\
\hline F6 & & & & .04310 & .84410 & .84880 \\
\hline \multirow[t]{2}{*}{ F7 } & & & & .04310 & .84607 & .85075 \\
\hline & & & & $\left(\mathrm{Na}_{3} \mathrm{~m}_{6} \mathrm{H}_{5} \mathrm{O}_{7}\right)$ & & \\
\hline F8 & .04300 & .04309 & .02510 & .014367 & & - \\
\hline F9 & .04300 & .04309 & .016448 & .014367 & .82930 & .83374 \\
\hline \multirow[t]{2}{*}{ F10 } & .04300 & .04309 & .008340 & .014367 & .84547 & .85019 \\
\hline & $E_{10}{ }^{\circ}$ & $E_{15}^{\circ}$ & $E_{20^{\circ}}$ & $E_{25}{ }^{\circ}$ & $E_{30^{\circ}}$ & $E_{35}^{\circ}$ \\
\hline F1.. & 0.82728 & 0.83168 & 0.83565 & 0.83951 & 0.84350 & 0.84737 \\
\hline F2 & .83832 & .84278 & .84698 & .85102 & .85534 & .85951 \\
\hline F3..- & .85544 & .86020 & .86473 & .86914 & .87359 & .87802 \\
\hline F4 & .82699 & .83130 & .83531 & .83921 & .84328 & .84724 \\
\hline F5 & .83824 & .84299 & .84719 & .85118 & $.855 ๖ 6$ & .85978 \\
\hline F6 & .85342 & .85824 & .86270 & .86712 & .87161 & .87609 \\
\hline F7 & .85540 & .86203 & .86471 & .86912 & .87368 & .87817 \\
\hline F8. & .82791 & .83223 & .83630 & .84025 & .84443 & .84848 \\
\hline F9 & .83812 & .84274 & .84701 & .85114 & .85541 & .85965 \\
\hline F10 & .85486 & .85964 & .86420 & .85863 & .87312 & .87770 \\
\hline
\end{tabular}


at $\mathrm{pH} 9.0$ could be changed only 0.1 percent by adding 0.05 mole of trisodium citrate to a liter of buffer. This change corresponds to 0.0004 in $\mathrm{pH}$ and $\mathrm{pK}$, or $0.02 \mathrm{mv}$ in emf. For the mixtures of series $\mathrm{E}$, in which the ratio of molality of the trisodium citrate to that of each buffer salt was 0.33 , the correction is even smaller.
The experimental data at $0^{\circ}$ to $60^{\circ} \mathrm{C}$ for mixtures containing trisodium citrate are listed in table 4. The results for solutions containing potassium nitrate $(R=1)$, sodium sulfate $(R=1)$, and trisodium citrate $(R=0.33)$, with varying ratios of sodium chloride to buffer, are given in table 5 .

\section{Second Dissociation Constant of $p$-Phenolsulfonic Acid}

Values of $\mathrm{p} K$, the negative of the common logarithm of the second dissociation constant (that of the phenol group) of $p$-phenolsulfonic acid were derived from the measurements of the solutions in series $\mathrm{A}, \mathrm{B}, \mathrm{C}, \mathrm{D}$, and $\mathrm{E}$ by the method described in an earlier section. Figure 1 is a plot of the values of $\mathrm{p} K^{\prime}$ at $25^{\circ} \mathrm{C}$ as a function of ionic strength for all five series. In table 6 , the values of $a^{*}$ that gave the best straight line for extrapola-

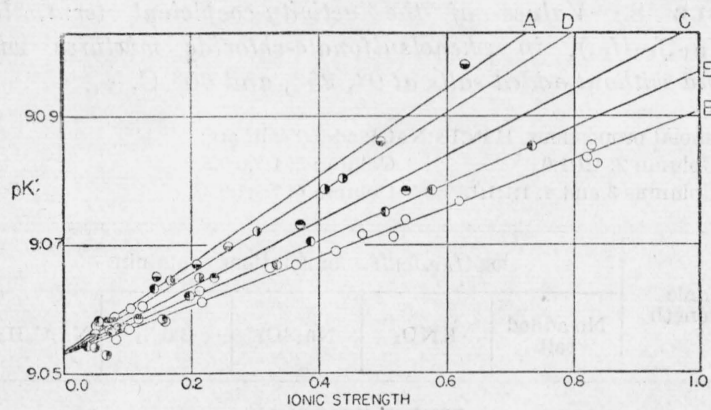

FIgURe 1.-Plots of $\mathrm{p} K^{\prime}$ as a function of ionic strength at $25^{\circ} \mathrm{C}$.

The letters indicate the series marking (tables 1 to 4 ) $\Theta=$ series $A ; \bigcirc=$ series $\mathrm{B} ; \mathrm{O}=$ series $\mathrm{C} ; \mathrm{O}=$ series $\mathrm{D} ; \mathrm{O}=$ series $\mathrm{E}$.

TABLe 6.-Values of $a^{*}$ and $\beta^{*}$ for five series of phenolsulfonate buffers at $0^{\circ}$ to $60^{\circ} \mathrm{C}$

\begin{tabular}{|c|c|c|c|c|c|c|c|c|c|c|}
\hline \multirow{2}{*}{$t$} & \multicolumn{2}{|c|}{$\begin{array}{c}\text { Series A, } \\
\mathrm{KNO}_{3}\end{array}$} & \multicolumn{2}{|c|}{$\begin{array}{l}\text { Series B, } \\
\mathrm{Na}_{2} \mathrm{SO}_{4}\end{array}$} & \multicolumn{2}{|c|}{$\begin{array}{l}\text { Series C, } \\
\mathrm{Na}_{2} \mathrm{SO}_{4}\end{array}$} & \multicolumn{2}{|c|}{$\begin{array}{l}\text { Series C, } \\
\mathrm{BaCl}_{2}\end{array}$} & \multicolumn{2}{|c|}{$\begin{array}{l}\text { Series E, } \\
\mathrm{Na}_{3} \mathrm{C}_{6} \mathrm{H}_{5} \mathrm{O}_{7}\end{array}$} \\
\hline & $a^{*}$ & $-\beta^{*}$ & $a^{*}$ & $-\beta^{*}$ & $a^{*}$ & $-\beta^{*}$ & $a^{*}$ & $-\beta^{*}$ & $a^{*}$ & $-\beta^{*}$ \\
\hline${ }^{\circ} \mathrm{C}$ & & & & & & & & & & \\
\hline $0 \ldots$ & 8.0 & 0.106 & 8.5 & 0.052 & 8. 3 & 0.061 & 7.7 & 0.086 & 8.5 & 0.057 \\
\hline $5 \ldots$ & 8. 0 & .100 & 8.5 & .046 & 8. 3 & .066 & 7. 7 & .082 & 8.5 & .054 \\
\hline 10 & 8.0 & .091 & 8.4 & .046 & 8. 2 & .062 & 7. 6 & .080 & 8.4 & .050 \\
\hline 15 & 8.0 & .087 & 8.4 & .042 & 8. 1 & .051 & 7.6 & .067 & 8.4 & .045 \\
\hline $20 \ldots$ & 8.0 & .078 & 8.3 & .039 & 8.1 & .049 & 7.5 & .070 & 8. 3 & .042 \\
\hline 25 & 8.0 & .072 & 8.2 & .036 & 8. 0 & .051 & 7.5 & .065 & 8. 2 & .044 \\
\hline 30 & 8.0 & .059 & 8.1 & .037 & 8.0 & .043 & 7.5 & .060 & 8.2 & .041 \\
\hline 35 & 8.0 & .052 & 8. 0 & .036 & 8.0 & .043 & 7.5 & .057 & 8. 2 & .036 \\
\hline 40 & 8.0 & .048 & 8.0 & .034 & 8.0 & .040 & 7.5 & .057 & 8. 2 & .034 \\
\hline $45 \ldots$ & 8.0 & .046 & 8.0 & .030 & 8. 0 & .039 & 7.5 & .051 & 8. 2 & .030 \\
\hline 50 & 8.0 & .039 & 8.0 & .027 & 8. 0 & .037 & 7.5 & .049 & 8. 2 & .026 \\
\hline $55 \ldots$ & 8.0 & .040 & 8.0 & .030 & 8.0 & 035 & 7.5 & .049 & 8. 2 & .024 \\
\hline $60 \ldots$ & 8.0 & .032 & 8.0 & .027 & 8. 0 & .032 & 7.5 & .047 & 8. 2 & .022 \\
\hline
\end{tabular}

tion and of $\beta^{*}$, the negative of the slope of this line, are listed for each series at each of the 13 temperatures.

The value of $m_{\mathrm{OH}}$ required for the hydrolysis correction was obtained conveniently from the emf data without the usual successive approximations by the relation [1]:

$$
\log m_{\mathrm{OH}}=\left(E-E^{\circ}\right) / k+\log m_{\mathrm{Cl}}-\mathrm{p} K_{\mathrm{w}},
$$

where $\mathrm{p} K_{\mathrm{w}}$ is the negative logarithm of the ionization constant of water. When $m_{\mathrm{OH}}$ was needed for buffers other than those for which emf data were available, it was computed from the approximation

$$
m_{\mathrm{OH}} \approx\left(K_{\mathrm{w}} / K\right) /\left(m_{1} / m_{2}\right) .
$$

Values of $K_{\mathrm{w}} / K$ at $0^{\circ}$ to $60^{\circ} \mathrm{C}$ are tabulated in the earlier paper [1]. Use of this approximate expression for $m_{\mathrm{OH}}$ introduces an error of about 0.002 unit in the $\mathrm{pH}$ of the $0.005-m$ phenolsulfonate buffer at $60^{\circ} \mathrm{C}$. The error decreases rapidly as the temperature is lowered or the concentration of buffer is increased. The ionic strength, $\mu$, and buffer ratio, $m_{\mathrm{HPs}} / m_{\mathrm{Ps}}$, are readily computed, with the aid of $m_{\mathrm{OH}}$, by the equations

$$
\mu=m_{1}+3 m_{2}+m_{3}+n m_{4}-m_{\mathrm{OH}}
$$

and

$$
m_{\mathrm{HPs}} / m_{\mathrm{Ps}}=\left(m_{1}+m_{\mathrm{OH}}\right) /\left(m_{2}-m_{\mathrm{OH}}\right) .
$$

The added salts were assumed to be completely ionized. ${ }^{3}$

A value of $\mathrm{p} K$ was computed from the emf measurement of each buffer solution at each temperature by eq 10 with the aid of $a^{*}$ and $\beta^{*}$ obtained by graphical means. The summary of $\mathrm{p} K$ (table 7) demonstrates the essential agree-

\footnotetext{
${ }^{3}$ As the added salt (with the exception of barium chloride) takes no part in the cell reaction, an exact knowledge of its molality is unnecessary. If 5 percent of this added salt were undissociated, the change in ionic strength would be insufficient to alter $\log \left(f_{\mathrm{HPs}} f_{\mathrm{Cl}} / f_{\mathrm{Ps}}\right)$ by 0.001 , as can be shown with the aid of eq 9 or table 8 . The value of $n$ accordingly was assumed to be 1 for potassium nitrate, 3 for barium chloride and sodium sulfate, and 6 for
} trisodium citrate. 
ment between the mean of the results of this investigation at each temperature with $\mathrm{p} K$ reported earlier [1]. The mean difference is less than 0.001 unit. At the higher temperatures, however, the deviations of each series from the mean are occasionally as large as 0.002 or 0.003 . In general, the solutions containing potassium nitrate or barium chloride were found to yield lower values of $\mathrm{p} K$ than did those to which sodium sulfate or trisodium citrate had been added. In view of the acceptable agreement between the two measurements of $\mathrm{p} K$, no recalculation of the thermodynamic constants for the dissociation of phenolsulfonate ion was made. Values of $\mathrm{E}^{\circ *}$ computed by eq 7 are given in the last column of the table.

\section{Effect of Neutral Salts on the Activity Coefficients}

With the aid of $a^{*}$ and $\beta^{*}$ from table 6 , a calculation of $\log \left(f_{\mathrm{HP}} f_{\mathrm{Cl}} / f_{\mathrm{Pa}_{\mathrm{B}}}\right)$ was made by eq 9 , in order to compare the values of this term at several ionic strengths and at temperatures of $0^{\circ}, 25^{\circ}$, and $60^{\circ} \mathrm{C}$. The results are shown in table 8 , where data for phenolsulfonate-chloride solutions without added salt are also given. For the latter, $a^{*}$ is 8.0 , and $\beta^{*}$ at $0^{\circ}, 25^{\circ}$, and $60^{\circ} \mathrm{C}$ has the values $-0.079,-0.057$, and -0.038 [4].

The change of the activity-coefficient term with the addition of neutral salt when the ionic strength remains unaltered is small, particularly at $25^{\circ} \mathrm{C}$ and higher temperatures. ${ }^{4}$ In these concentrations, therefore, the added salts probably effect no large change in the electrostatic character of the buffer medium. The small effect of salt is evident in figure 2, where the activity-coefficient term and $\left(E-E^{\circ}\right) / k+\log \left(m_{\mathrm{HPs}} m_{\mathrm{Cl}} / m_{\mathrm{Ps}}\right)$ are plotted as a function of the square root of the ionic strength.

\section{Buffer Solutions Without Added Salt}

A determination of the effect of a changing ratio of sodium chloride on $a^{*}$ and $\beta^{*}$ was reported earlier [4]. As in the present work, the $1: 1$ phenolsulfonate buffer was studied by means of emf measurements at $0^{\circ}$ to $60^{\circ} \mathrm{C}$. The value of

\footnotetext{
4 Nims [6] has determined $-\log \left(f_{\mathrm{Cl}} f_{\mathrm{HG}} / f_{\mathrm{G}}\right)$, where G represents the singly charged glycolate anion, in glycolate buffer solutions containing chloride and has found a pronounced salt effect. Three series of solutions, in which the cation was respectively potassium, lithium, and barium, gave quite different values for the activity-coefficient term.
}

TABLE 7.-Summary of values of $\mathrm{p} K$ for the second dissociation of p-phenolsulfonic acid and $E^{\circ *}$ at $0^{\circ}$ to $60^{\circ} \mathrm{C}$

\begin{tabular}{|c|c|c|c|c|c|c|c|}
\hline$t$ & $\begin{array}{c}\text { Series } \\
\mathrm{A} \\
\mathrm{KNO}_{3}\end{array}$ & $\left|\begin{array}{c}\text { Series } \\
\mathrm{B}, \mathrm{C}, \\
\mathrm{Na}_{2} \mathrm{SO}_{4}\end{array}\right|$ & $\begin{array}{c}\text { Series } \\
\mathrm{D} \\
\mathbf{B a C l}_{2}\end{array}$ & $\begin{array}{c}\text { Series E, } \\
\mathrm{Na}_{3} \mathrm{C}_{6} \mathrm{H}_{5} \mathrm{O}_{7}\end{array}$ & Mean & RP1559 & $E^{\circ *}$ \\
\hline${ }^{\circ} C$ & 9.3541 & 9.3528 & 9. 3498 & 9. 3524 & 9.352 & 9. 352 & $\begin{array}{l}\text { Int. } v \\
0.74313\end{array}$ \\
\hline $5 \ldots$ & 9.2856 & 9. 2841 & 9. 2818 & 9. 2830 & 9.284 & 9.284 & .74616 \\
\hline 10 & 9.2203 & 9.2201 & 9. 2187 & 9. 2206 & 9.220 & 9.220 & .74912 \\
\hline 15 & 9.1606 & 9. 1612 & 9.1593 & 9.1593 & 9.160 & 9.160 & .75195 \\
\hline $20 \ldots$ & 9.1038 & 9.1052 & 9.1033 & 9.1034 & 9.104 & 9.105 & .75490 \\
\hline $25 \ldots$ & 9.0527 & 9.0540 & 9.0514 & 9.0534 & 9.053 & 9.053 & .75777 \\
\hline $30 \ldots$ & 9. 0052 & 9.0063 & 9.0038 & 9.0053 & 9.005 & 9.005 & .76058 \\
\hline 35 & 8. 9585 & 8. 9626 & 8. 9591 & 8.9618 & 8.961 & 8.961 & .76334 \\
\hline $40 \ldots$ & 8.9190 & 8.9221 & 8. 9176 & 8.9205 & 8.920 & 8.921 & .76609 \\
\hline $45 \ldots$ & 8.8805 & 8.8863 & 8.8811 & 8. 8849 & 8.883 & 8.883 & .76883 \\
\hline 50 & 8.8480 & 8.8520 & 8.8472 & 8.8511 & 8.850 & 8.849 & .77161 \\
\hline 55 & 8. 8144 & 8.8183 & 8. 8143 & 8.8195 & 8.817 & 8.816 & .77423 \\
\hline 60 & 8. 7868 & 8. 7888 & 8. 7845 & 8. 7884 & 8.787 & 8.787 & .77683 \\
\hline
\end{tabular}

TABLE 8.-Values of the activity-coefficient term, log $\left(f_{\mathrm{HPs}} f_{\mathrm{C} 1} / f_{\mathrm{Ps}_{\mathrm{s}}}\right)$, in phenolsulfonate-chioride mixtures with and without added salts at $0^{\circ}, 25^{\circ}$, and $60^{\circ} \mathrm{C}$.

The molal proportions, HPs:Ps:NaCl: added salt, are: Column 2; 1:1:1:0. Column 5; 1:1:0:0.5.

Columns 3 and $4 ; 1: 1: 1: 1 . \quad$ Column $6 ; 1: 1: 1: 0.33$.

\begin{tabular}{|c|c|c|c|c|c|}
\hline \multirow{2}{*}{$\begin{array}{l}\text { Ionic } \\
\text { strength }\end{array}$} & \multicolumn{5}{|c|}{$\log \left(f_{\mathrm{HPs}} f_{\mathrm{Cl}} / f_{\mathrm{Ps}}\right)$ for solutions containing- } \\
\hline & $\begin{array}{l}\text { No added } \\
\text { salt }\end{array}$ & $\mathrm{KNO}_{3}$ & $\mathrm{Na}_{2} \mathrm{SO}_{4}$ & $\mathrm{BaCl}_{2}$ & $\mathrm{Na}_{3} \mathrm{C}_{6} \mathrm{H}_{5} \mathrm{O}$ \\
\hline \multicolumn{6}{|c|}{ TEMPERATURE $0^{\circ} \mathrm{C}$} \\
\hline 0.02 & 0.099 & 0.099 & 0.098 & 0.100 & 0.098 \\
\hline .05 & .134 & .133 & .133 & .136 & .132 \\
\hline $.1 \ldots$ & .162 & .159 & .160 & .164 & .159 \\
\hline $.2 \ldots$ & .186 & .181 & .185 & .189 & .184 \\
\hline .3 & .197 & .189 & .198 & .200 & .196 \\
\hline .5 & .204 & .191 & .208 & .207 & .206 \\
\hline .6 & .204 & .188 & .210 & .206 & .207 \\
\hline
\end{tabular}

TEMPERATURE $25^{\circ} \mathrm{C}$

\begin{tabular}{r|r|r|r|r|r}
\hline 0.02 & 0.104 & 0.104 & 0.104 & 0.105 & 0.103 \\
.05 & .140 & .140 & .140 & .143 & .140 \\
.170 & .169 & .170 & .174 & .169 \\
.2198 & .195 & .199 & .203 & .198 \\
.5 & .198 & .213 & .218 & .212 \\
\hline .6 & .211 & .207 & .230 & .230 & .226 \\
\hline
\end{tabular}

TEMPERATURE $60^{\circ} \mathrm{C}$

\begin{tabular}{|c|c|c|c|c|c|}
\hline $0.02 \ldots$ & 0.111 & 0.111 & 0.111 & 0.112 & 0.110 \\
\hline 05 & .150 & .150 & .150 & .153 & .149 \\
\hline 1 & .182 & .183 & .183 & .187 & .182 \\
\hline $.2 \ldots$ & .214 & .215 & .216 & .219 & .214 \\
\hline 3 & .230 & .232 & .233 & .236 & .231 \\
\hline 5 & .247 & .250 & .252 & .253 & .250 \\
\hline 6 & .251 & .255 & .258 & .258 & .256 \\
\hline
\end{tabular}



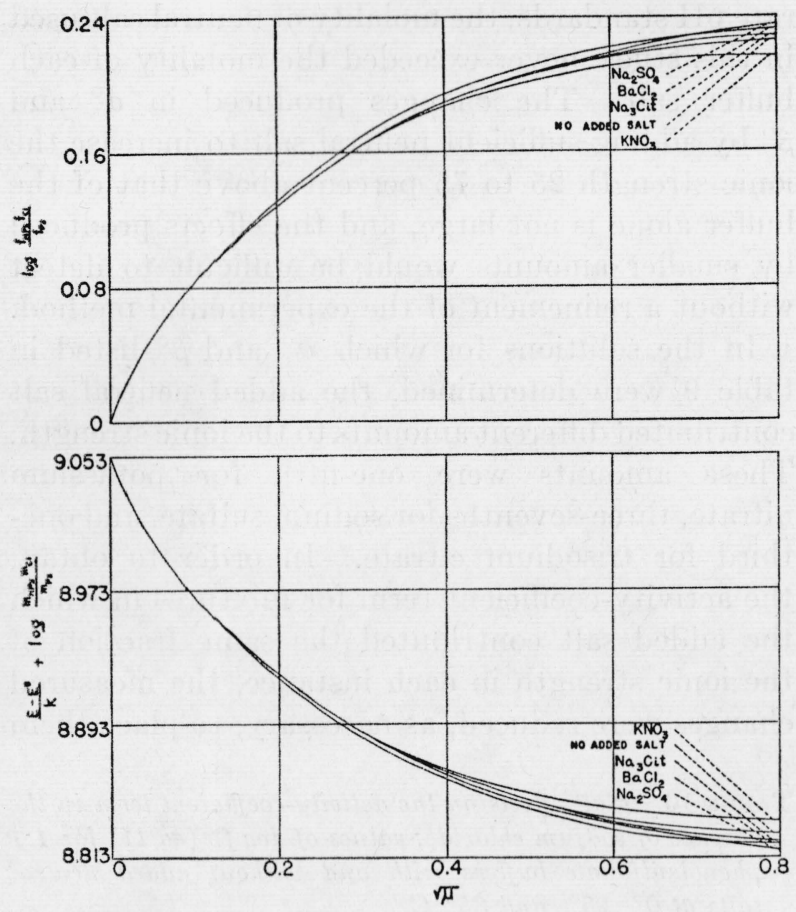

Figure 2.-Salt effect on the activity-coefficient term (uppercurve) and on $\left(E-E^{\circ}\right) / k+\log \left(m_{\mathrm{HP}} m_{\mathrm{Cl}} / m_{\mathrm{Ps}}\right)$ (lower curve) at $25^{\circ} \mathrm{C}$. Compare eq 9 and 10 .

$a^{*}$ was found to be $8.0 \mathrm{~A}$ at all temperatures and to be substantially unchanged when the molal ratio of sodium chloride to each buffer salt was reduced from unity to one-tenth. The parameter $\beta^{*}$ was negative and changed in a regular manner as the temperature was increased.

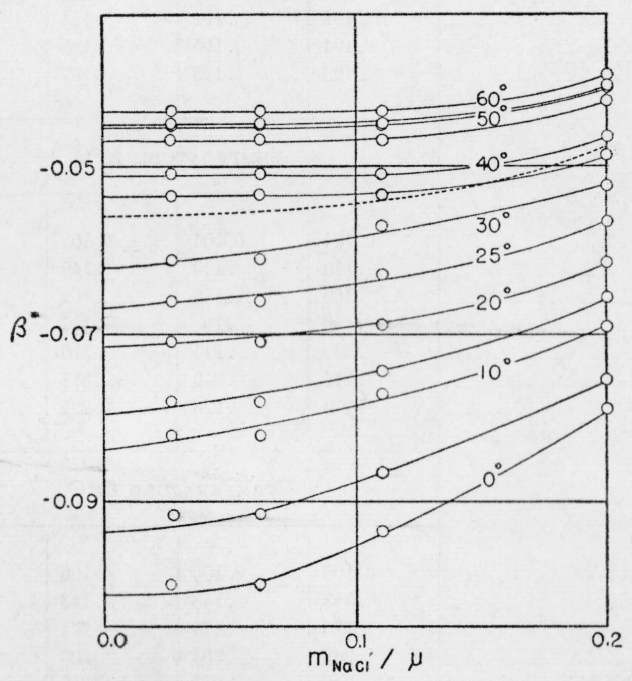

FIGURE 3.-Plots of $\beta^{*}$ as a function of $m_{\mathrm{NaCl}} / \mu$ for $1: 1$ phenolsulfonate buffers with varying amounts of sodium chloride.
Figure 3 shows the change of $\beta^{*}$ with the ratio of sodium chloride to buffer salt. The limiting values, $\beta^{\circ}$, are given in table 9 . The value of $a^{\circ}$ is $8.0 \mathrm{~A}$ at each temperature.

TABLE 9.-Values of $a^{\circ}$ and $\beta^{\circ}$ for 1:1 phenolsulfonate buffers withoui added salt and for buffers containing potassium nitrate, sodium sulfate and trisodium citrate (molality of added neutral salt)/(molality of each buffer $s a l t)=1\left(\mathrm{KNO}_{3}\right) ; 1\left(\mathrm{Na}_{2} \mathrm{SO}_{4}\right) ;$ and $1 / 3\left(\mathrm{Na}_{3} \mathrm{C}_{6} \mathrm{H}_{5} \mathrm{O}_{7}\right)$.

\begin{tabular}{|c|c|c|c|c|c|c|c|c|}
\hline & \multicolumn{2}{|c|}{$\begin{array}{l}\text { Without added } \\
\text { salt }\end{array}$} & \multicolumn{2}{|c|}{$\mathrm{KNO}_{3}$} & \multicolumn{2}{|c|}{$\mathrm{Na}_{2} \mathrm{SO}_{4}$} & \multicolumn{2}{|c|}{$\mathrm{Na}_{3} \mathrm{C}_{6} \mathrm{H}_{5} \mathrm{O}_{7}$} \\
\hline & $a^{\circ}$ & $\beta^{\circ}$ & $a^{\circ}$ & $\beta^{\circ}$ & $a^{\circ}$ & $\beta^{\circ}$ & $a^{\circ}$ & $\beta^{\circ}$ \\
\hline${ }^{\circ} \mathrm{C}$ & & & & & & & & \\
\hline $0 \ldots$ & 8.0 & -0.101 & 8. 0 & -0.098 & 8.5 & -0.046 & 8.5 & -0.058 \\
\hline $5 \ldots \ldots$ & 8.0 & -.094 & 8.0 & -.087 & 8.5 & -.046 & 8.5 & -.058 \\
\hline $10 \ldots$ & 8.0 & -.085 & 8. 0 & -.078 & 8.4 & -.046 & 8.4 & -.058 \\
\hline $15 \ldots$ & 8.0 & -.080 & 8.0 & -.070 & 8.4 & -.046 & 8.4 & -.058 \\
\hline $20 \ldots . .$. & 8.0 & -.072 & 8.0 & -.063 & 8.3 & -.046 & 8.3 & -.058 \\
\hline $25 \ldots$ & 8.0 & -.066 & 8.0 & -.058 & 8.2 & -.046 & 8.2 & -.058 \\
\hline $30 \ldots$ & 8.0 & -.063 & 8.0 & -.0 & 8.1 & -.046 & 8.2 & -.058 \\
\hline $35 \ldots$ & 8.0 & -.053 & 8.0 & -.048 & 8.0 & -.046 & 8.2 & -.058 \\
\hline $40 \ldots$ & 8.0 & -.051 & & & & & & \\
\hline $45 \ldots .$. & 8.0 & -.047 & & & & & & \\
\hline $50 \ldots$ & 8.0 & -.045 & & & & & & \\
\hline $55 \ldots$ & 8.0 & -.045 & & & & & & \\
\hline $60 \ldots$ & 8.0 & -.043 & & & & & & \\
\hline
\end{tabular}

\section{Buffer Solutions With Added Salt}

The interdependence of $a^{*}$ and $\beta^{*}$ is noteworthy. ${ }^{5}$ It is ordinarily difficult, in view of the normal experimental error of a series of points, to establish the correct value of $a^{*}$ within 0.1 to 0.2 A by choice of the value that yields the best straight line. An error of this magnitude in $a^{*}$ is, fortunately, offset almost completely by a compensatory change in $\beta^{*}$. For example, if 8.2 A were chosen for $a^{*}$, instead of $8.0 \mathrm{~A}$, in the mixtures with varying amounts of sodium chloride but without added neutral salt, the plot of $\beta^{*}$ at $25^{\circ} \mathrm{C}$ with respect to the fractional contribution of sodium chloride to the ionic strength would follow the dashed line of figure 3 , and $\beta^{\circ}$ would be assigned a value of -0.056 instead of -0.066 . With the use of $a^{\circ}=8.2$ and $\beta^{\circ}=-0.056, \log f_{\boldsymbol{R}}^{\circ}$ for the $0.1-m$ buffer (ionic strength of 0.4 ) calculated from eq 11 would be 0.2157 instead of 0.2154 at $25^{\circ} \mathrm{C}$, and at an ionic strength of 0.01 , the difference would be 0.0006 .

Advantage was taken of this agreement in

\footnotetext{
6 Van Rysselberghe and Eisenberg [7] and Robinson and Harned [8] have suggested modifications of the Hückel equation, in which a single parameter expresses successfully the activity coefficient of the alkali halides and hydrogen halides up to concentrations of 1 to $4 \mathrm{~m}$.
} 
determining the limiting parameters for buffers that contained neutral salt in the absence of sodium chloride. For the complete analysis of the data of series $\mathrm{F}$ given in table 5 , it was not necessary to have an independent measure of $a^{*}$ for each ratio of sodium chloride to buffer and neutral salt. Such a determination would require the study of several dilutions of each mixture of series F. Instead, $a^{*}$ for the appropriate mixture of buffer and salt was selected from table $6, \mathrm{p} K^{\prime}$ was computed for each solution at each temperature, and $\beta^{*}$ was evaluated from the relation,

$$
\beta^{*}=\left(\mathrm{p} K-\mathrm{p} K^{\prime}\right) / \mu
$$

Plots of $\beta^{*}$ as a function of $m_{\mathrm{NaCl}} / \mu$ were constructed, and $\beta^{\circ}$, the intercept for zero concentration of sodium chloride, was found. Five experimental points determined the extrapolation for solutions that contained sodium sulfate, whereas measurements that represented four different ratios of sodium chloride to buffer were available for solutions with potassium nitrate and trisodium citrate. The limiting parameters for the mixtures containing neutral salt are given in table 9, together with those for the 1:1 buffer without added salt. The data for solutions with varying contents of sodium chloride did not extend above $35^{\circ} \mathrm{C}$. The parameter $\beta^{\circ}$ has constant values of -0.046 and -0.058 , within 0.004 , for the mixtures with sodium sulfate and trisodium citrate, respectively, in this range of temperatures. The limiting values of $\beta^{*}$ are thought to be correct to \pm 0.006 . This uncertainty corresponds to an error of 0.003 in the activity-coefficient term at an ionic strength of 0.5 .

It is now possible, with eq 11 and the constants given in table 9 , to compute $\log f_{R}^{\circ}$ for $1: 1$ phenolsulfonate buffers that contain potassium nitrate or sodium sulfate in molalities equal to that of each buffer salt, or trisodium citrate in one-third the molality of the buffer. Furthermore, the value of this activity-coefficient term is likewise known for the same buffer in the absence of salt. The change which results from adding a single definite amount of each of three neutral salts of different valence types to a 1:1 phenolsulfonate buffer has therefore been determined, but the effect of other concentrations of salt, larger or smaller than this one, is still unknown. Inasmuch as the effect on the $\mathrm{pH}$ of relatively small amounts of salt is of most concern in the preparation and use of accu- rate $\mathrm{pH}$ standards, the molality of neutral salt used in this study never exceeded the molality of each buffer salt. The changes produced in $a^{\circ}$ and $\beta^{\circ}$ by adding sufficient neutral salt to increase the ionic strength 25 to 75 percent above that of the buffer alone is not large, and the effects produced by smaller amounts would be difficult to detect without a refinement of the experimental method.

In the solutions for which $a^{\circ}$ and $\beta^{\circ}$ listed in table 9 were determined, the added neutral salt contributed different amounts to the ionic strength. These amounts were one-fifth for potassium nitrate, three-sevenths for sodium sulfate, and onethird for trisodium citrate. In order to obtain the activity-coefficient term for mixtures in which the added salt contributed the same fraction of the ionic strength in each instance, the measured changes were reduced, as necessary, to place them

TABLE 10.- Salt effects on the activity-coefficient term in the absence of sodium chloride; values of $\log f_{R}^{\circ}(e q 11)$ for 1:1 phenolsulfonate buffers with and without added neutral salts at $0^{\circ}, 25^{\circ}$, and $35^{\circ} \mathrm{C}$

The added salts contribute one-ffth of the inoic strength in each case.

\begin{tabular}{|c|c|c|c|c|}
\hline \multirow{2}{*}{ Ionic strength } & \multicolumn{4}{|c|}{$\log f_{R}$ for buffer solutions containing- } \\
\hline & $\begin{array}{l}\text { No added } \\
\text { salt }\end{array}$ & $\mathrm{KNO}_{3}$ & $\mathrm{Na}_{2} \mathrm{SO}_{4}$ & $\mathrm{Na}_{3} \mathrm{C}_{6} \mathrm{H}_{5} \mathrm{O}_{7}$ \\
\hline & \multicolumn{4}{|c|}{ TEMPERATURE $0^{\circ} \mathrm{C}$} \\
\hline $002 \ldots$ & 0.099 & 0.099 & 0.088 & 0.098 \\
\hline $.05_{\ldots}$ & .133 & .133 & .133 & .132 \\
\hline $.1 \ldots \ldots$ & .160 & .160 & .160 & .159 \\
\hline $.2 \ldots$ & .182 & .183 & .183 & .183 \\
\hline $3 \ldots$ & .191 & .192 & .194 & .193 \\
\hline $.4 \ldots$ & .194 & .195 & .198 & .198 \\
\hline \multirow[t]{2}{*}{.5} & .193 & .195 & .199 & .199 \\
\hline & \multicolumn{4}{|c|}{ TEMPERATURE $25^{\circ} \mathrm{C}$} \\
\hline $.02 \ldots$ & 0.104 & 0.104 & 0.103 & 0.103 \\
\hline .05 & .140 & .140 & .140 & .139 \\
\hline $1 \ldots$ & .169 & .170 & .169 & .168 \\
\hline $.2 \ldots$ & .196 & , 198 & .197 & .195 \\
\hline $.3 \ldots$ & .209 & .211 & .210 & .208 \\
\hline . $4 \ldots . .$. & .215 & .219 & .217 & .215 \\
\hline \multirow[t]{2}{*}{.5 } & .219 & .223 & .221 & .219 \\
\hline & \multicolumn{4}{|c|}{ TEMPERATURE $35^{\circ} \mathrm{C}$} \\
\hline $.02 \ldots$ & 0.106 & 0.106 & 0.106 & 0.105 \\
\hline $.05 \ldots$ & .143 & .143 & .143 & .142 \\
\hline $11 \ldots+\ldots$ & .173 & .174 & .174 & .172 \\
\hline .2 & $\because 202$ & .203 & .203 & .200 \\
\hline $.3 \ldots \ldots \ldots$ & .216 & .217 & .217 & .214 \\
\hline 4 & .224 & .226 & .225 & .221 \\
\hline .5 & .229 & .231 & .230 & .225 \\
\hline
\end{tabular}


on a common basis, in direct proportion to the fractional contribution of the salt to the ionic strength. The largest of the measured salt effects was 0.018 , found when sodium sulfate $(R=1)$ was present at $0^{\circ} \mathrm{C}$ and an ionic strength of 0.5 . In view of the relatively small effects involved, this procedure for computing the effect of amounts of salt smaller than those actually used was considered justifiable. ${ }^{6}$ A comparison of $\log f_{\mathrm{R}}^{\circ}$ for solutions in which the added salt makes up onefifth of the total ionic strength is given in table 10 .

No specific effects larger than the uncertainty of measurement are apparent in the data of table 10. The effectiveness of salts of the $1-1,1-2$, and 1-3 valence types at equal ionic strengths in altering the activity coefficients is nearly the same, and no marked abnormal influence of the increased ionic charge is evident. Furthermore, the salt effect of each of the three salts is no larger

\footnotetext{
${ }^{8}$ By analogy with mixtures of strong electrolytes, $\log f_{\mathrm{R}}^{\circ}$ at a given ionic strength is expected to vary in an approximately linear manner with change of composition, provided that the contribution of the salt to the ionic strength of the mixture is plotted. For a review of this topic, see chapter 15 of the monograph by Harned and Owen [9].
}

than the combined uncertainties inherent in the determination of $\beta^{\circ}$ and in the experimental measurements, or 0.006 at an ionic strength of 0.5 . Changes larger than the estimated limits of error are found, as expected, for mixtures in which sodium sulfate and trisodium citrate contribute more than one-fifth of the ionic strength.

If, indeed, the change of $\log f_{R}^{\circ}$ with addition of neutral salt approximates in character the behavior of $\log \left(f_{\mathrm{HP}_{\mathrm{s}}} / f_{\mathrm{Ps}}\right)$, it can be concluded that the effect of neutral salts in moderate concentrations on the $\mathrm{pH}$ of phenolsulfonate buffer solutions is governed primarily by the increase in ionic strength and not by the specific nature of the salt itself. When the added salt makes up onefifth or less of the ionic strength, the pH of the solution is close to that of a solution of the pure buffer of the same total ionic strength. ${ }^{7}$

\footnotetext{
7 Evidently the effect of salts on the negative of the common logarithm of the activity of hydrogen ion will be quite difierent from the change produced in $-\log m_{\mathrm{H}}$ or $-\log c_{\mathrm{H}}$, often considered to measure the salt effect on the $\mathrm{pH}$ (see, for example, reference 10). In general, addition of salt to a dilute solution of a weak acid causes $m_{\mathrm{H}}$ to increase and $f_{\mathrm{H}}$ to decrease. Hence, the product of these two quantities, the activity, may change less than does the concentration alone.
}

\section{References}

[1] R. G. Bates, G. L. Siegel, and S. F. Acree, J. Research NBS 31, 205 (1943) RP1559.

[2] W. J. Hamer, J. O. Burton, and S. F. Acree, J. Research NBS 24, 269 (1940) RP1284.

[3] H. S. Harned and R. W. Ehlers, J. Am. Chem. Soc. 55, 2179 (1933).

[4] R. G. Bates and S. F. Acree, J. Research NBS 32, 131 (1944) RP1580.

[5] R. G. Bates and S. F. Acree, J. Research NBS 30, 129 (1943) RP1524.

[6] L. F. Nims, J. Am. Chem. Soc. 58, 987 (1936).
[7] P. Van Rysselberghe and S. Eisenberg, J. Am. Chem. Soc. 61, 3030 (1939); 62, 451 (1940).

[8] R. A. Robinson and H. S. Harned, Chem. Rev. 28, 419 (1941).

[9] H. S. Harned and B. B. Owen, Physical chemistry of electrolytic solutions (Reinhold Publishing Corporation, New York, N. Y., 1943).

[10] E. Güntelberg and E. Schiödt, Z. physik. Chem. A135, 393 (1928).

Washington, June 3, 1946. 